\title{
PENERAPAN PRINSIP KEHATI-HATIAN PERBANKAN (PRUDENTIAL BANKING) DALAM PROSES PENYALURAN KREDIT PERBANKAN DI INDONESIA
}

Oleh:

\author{
Darwance* $^{*}$ \\ Email: darwance@yahoo.co.id
}

\begin{abstract}
As a financial institution which as intermediating function, bank has to re-distribute credits relied on collected funding from the people, thus the funding circle works properly. Article 2 Banking Law decrees that in applying duties Indonesian banking as based on Pancasila and Constitution of Republic of Indonesia 1945 of years by using orudent principal. Ignorance of prudential banking in credit distributional process contained in $5 C$ principle and other well-known principles lead to the danger in the existence of banking industries.
\end{abstract}

Keywords : Prudent Principle, Banking, Credit

\section{A. PENDAHULUAN}

Sektor perbankan merupakan salah satu sektor terpenting dalam proses pembanguan sebuah negara, tidak terkecuali bagi negara berkembang, seperti Indonesia. Bank merupakan satu lembaga yang mempunyai peran sangat penting dalam mendorong pertumbuhan perekonomian suatu negara, bahkan pertumbuhan bank suatu negara dipakai sebagai ukuran pertumbuhan perekonomian negara yang bersangkutan. ${ }^{1}$ Dunia perbankan berdasarkan fakta empiris selama ini

*Dosen Tetap Fakultas Hukum Universitas Bangka Belitung.

${ }^{1}$ Ismail, Manajemen Perbankan dari Teori Menuju Aplikasi, Kencana Prenada Media Group, Jakarta, 2011, hlm. 1. telah membuktikan dirinya mampu menunjukkan peran positif dalam mempertahankan suatu bangsa dari bayang-bayang krisis ekonomi, dibuktikan dengan keberanian bank dalam mengucurkan bantuan finansial berupa pemberian kredit kepada pihak tertentu.

Seiring akan diberlakukannya ASEAN Free Trade Area (AFTA) yang mengintegrasi sektor perbankan antar sesama negara-negara anggota, sejumlah bank-bank asing pun diprediksi akan turut berkompetisi dengan bank-bank dalam negeri dalam menawarkan produk perbankan di Indonesia. Dengan demikian, perbankan dalam negeri dituntut berinovasi dan memodifikasi 
produk perbankan untuk
mempertahankan atau bahkan
meningkatkan tingkat kepercayaan
masyarakat terhadap perbankan
dalam negeri.

Sebagai lembaga yang menjalankan fungsi intermediasi, bank tentu harus kembali menyalurkan kredit yang bersumber dari dana yang dihimpun dari masyarakat dengan tujuan agar perputaran uang berjalan sebagaimana mestinya. Dalam menjalankan fungsi intermediasinya, salah satu tugas perbankan adalah menyalurkan dana kepada masyarakat dalam bentuk kredit. Masyarakat sebaliknya membutuhkan kredit, salah satunya dari dunia perbankan, karena masyakarat memiliki kebutuhan yang mendesak menuntuk untuk segera dipenuhi. Posisi bank selaku kreditur tidak sembarangan dalam meminjamkan uangnya. Mereka mempunyai berbagai penilaian terhadap debitur untuk menghindari terjadinya masalah yang timbul di kemudian hari setelah transaksi utang piutang selesai dilakukan, salah satunya adalah berkaitan dengan kepercayaan pengembalian utang. ${ }^{2}$ Operasi bank di bidang pemberian fasilitas kredit, merupakan salah satu fungsi bank yang sekaligus merupakan sumber profit paling tinggi bagi usaha perbankan, sejalan dengan risiko yang tinggi pula.

Selaku pemberi fasilitas kredit, tugas bank tidak hanya sekedar melakukan penandatanganan perjanjian kredit dan menagih pembayaran angsuran kepada debiturnya, tetapi bank sejatinya juga harus memberikan bimbingan dan pengarahan. Hal ini penting dilakukan untuk mengantisipasi terjadinya pelanggaran penggunanaan fasilitas kredit yang dapat berujung pada timbulnya sejumlah masalah yang dapat menganggu proses pembayaran kembali.

Di samping itu, bank juga seharusnya tidak boleh hanya memberikan utang tanpa mengetahui apa yang dilakukan nasabahnya setelah menerima utang. Identitas dan aktivitas penerima utang dari bank pun harus diketahui secara mendalam oleh pihak bank. Apabila sampai terjadi hal tersebut di atas,

${ }^{2}$ Gatot Supramono, Perbankan dan Masalah Kredit Suatu Tinjauan di Bidang Yuridis, Rineka Cipta, Jakarta, 2009, hlm. 1. 
maka bukan tidak mungkin bank yang bersangkutan akan mendapat penilaian buruk oleh karena tidak melakukan prinsip kehati-hatian, sehingga akan berakibat fatal pada kinerja serta kehidupan perbankan itu sendiri. Apalagi perbankan adalah salah satu sektor yang selalu diancam krisis, salah satunya yang paling mengancam adalah kredit macet (debt crisis). ${ }^{3}$

Angka kredit macet yang tinggi dalam industri perbankan secara bersamaan ikut mempengaruhi kinerja pemerintah, khususnya dalam bidang ekonomi. Oleh sebab itu pemerintah dalam Undang-Undang Nomor 10 Tahun 1998 Tentang Perubahan Atas Undang-Undang Nomor 7 Tahun 1992 Tentang Perbankan (UU Perbankan) pun telah memberikan semacam patokan bagi bank dalam menyalurkan kredit, sebagaimana yang tertuang dalam Pasal 2 yang menegaskan, bahwa perbankan Indonesia dalam melakukan usahanya berasaskan demokrasi ekonomi dengan menggunakan prinsip kehati-hatian. Setiap proses pemberian kredit terlebih dahulu haruslah diadakan penelitian/analisis yang mendalam

\footnotetext{
${ }^{3}$ Ibid., hlm. 9.
}

dari berbagai aspek, tak terkecuali aspek hukum. ${ }^{4}$

Namun demikian, tampaknya acuan tersebut belum sepenuhnya mampu menanggulangi terjadinya kredit macet dalam usaha perbankan. Indikasinya adalah masih tingginya angka kredit macet di Indonesia. Gazali dan Usman mengemukakan, bahwa meskipun salah analisis kredit sebagai manifestasi dari prinsip kehati-hatian bukanlah merupakan penyebab utama kredit macet, akan tetapi sebagian besar kredit macet terjadi akibat salah dalam melakukan analisis. $^{5}$

Dari uraian di atas jelaslah, bahwa penerapan prinsip kehatihatian sebagaimana yang diamanatkan dalam UU Perbankan di Indonesia selama ini mempunyai hubungan kausalitas terhadap proses penyaluran kredit perbankan. Dengan demikian, perlu dilakukan kajian tentang penerapan prinsip kehati-hatian perbankan (prudential banking) sebagaimana yang diatur secara yuridis dalam UU Perbankan dalam proses penyaluran perbankan

${ }^{4}$ HR.R. Daeng Naja, Hukum Kredit dan Bank Garansi, Citra Aditya Bakti, Bandung, 2005, hlm. 21-22.

${ }^{5}$ Djoni S., Gazali dan Rachmadi Usman, Hukum Perbankan, Sinar Grafika, Jakarta, 2012, hlm. 268. 
di Indonesia serta implikasi pengabaiannya.

\section{B. METODE PENELITIAN}

Penelitian ini merupakan penelitian yuridis normatif yang meneliti hukum dari perspektif internal dengan objek penelitiannya adalah norma hukum. ${ }^{6}$ Penelitian ini menggunakan pendekatan undangundang-undang (statute approach) dan pendekatan kasus (case approach). Pendekatan undangundang-undang (statute approach) dilakukan dengan menelaah semua undang-undang dan regulasi yang bersangkut paut dengan isu hukum yang sedang ditangani. ${ }^{7}$ Sedangkan pendekatan kasus (case approach) dilakukan dengan cara melakukan telaah terhadap kasus-kasus yang berkaitan dengan isu yang dihadapi yang telah menjadi putusan pengadilan yang telah mempunyai kekuatan hukum tetap, dapat berupa kasus yang terjadi di Indonesia maupun di negara lain. ${ }^{8}$

${ }^{6}$ I Made Pasek Diantha, Metodologi Penelitian Hukum Normatif dalam Justifikasi Teori Hukum, Kencana Prenada Media Group, Jakarta, 2017, hlm. 12.

${ }^{7}$ Peter Mahmud Marzuki, Penelitian Hukum (Edisi Revisi), Kencana Prenada Media Group, Jakarta, 2016, hlm. 133.

${ }^{8}$ Ibid., hlm. 134.

\section{PEMBAHASAN}

Ketentuan Pasal 1 angka 1 UU Perbankan menyatakan bahwa perbankan adalah segala sesuatu yang menyangkut tentang bank, mencakup tentang kelembagaan, kegiatan usaha, serta cara dan proses dalam melaksanakan kegiatan usahanya. Sementara Pasal 1 angka 2 UU Perbankan menyatakan bahwa bank adalah badan usaha yang menghimpun dana dari masyarakat dalam bentuk simpanan dan menyalurkannya kepada masyarakat dalam bentuk kredit dan/ atau bentuk-bentuk lainnya dalam rangka meningkatkan taraf hidup rakyat banyak.

Dari pengertian bank secara yuridis, jelas bahwa bank berfungsi sebagai financial intermediary dengan usaha utama menghimpun dan menyalurkan dana masyarakat serta memberi jasa-jasa lainnya yang lazim dilakukan oleh bank dalam lalu lintas pembayaran. Sebagai badan usaha, bank akan selalu berusaha mendapatkan keuntungan yang sebesar-besarnya dari usaha yang dijalankannya, sedangkan sebagai lembaga keuangan bank mempunyai kewajiban untuk menjaga kestabilan nilai uang, 
mendorong kegiatan ekonomi, dan perluasan kesempatan kerja. ${ }^{9}$

Merujuk pada definisi bank secara yuridis yang tertuang dalam peraturan perundang-undangan, Kasmir menjelaskan secara lebih luas lagi, bahwa bank merupakan perusahaan yang bergerak di bidang keuangan, artinya aktivitas perbankan selalu berkaitan dalam bidang keuangan, yang menghimpun dana dari masyarakat luas (funding) dalam bentuk simpanan, dan kemudian dana dalam bentuk simpanan tersebut diputar kembali atau dijual kembali ke masyarakat dalam bentuk pinjaman atau lebih dikenal dengan istilah kredit (lending). ${ }^{10}$

Bagi bank konvensional, dalam memberikan pinjaman di samping dikenakan bunga, juga dikenakan jasa pinjaman bagi penerima pinjaman (debitur) dalam bentuk biaya administrasi serta biaya provisi dan komisi. ${ }^{11}$ Selain itu, keuntungan utama diperoleh dari selisih bunga simpanan yang diberikan kepada

${ }^{9}$ Djoni S. Gazali dan Rachmadi Usman, Op. Cit., hlm. 136.

${ }^{10}$ Kasmir, Bank dan Lembaga Keuangan Lainnya (Edisi Keenam), PT. Raja Grafindo Persada, Jakarta, 2002, hlm. 23-24.

${ }^{11}$ Martono, Bank dan Lembaga Keuangan Lainnya, Ekonisia Fakultas Ekonomi Universitas Islam Indonesia, Yogyakarta, 2004, hlm. 25. penyimpan dengan bunga pinjaman atau kredit yang diberikan, dikenal dengan istilah spread based. ${ }^{12}$ Perlu diketahui bahwa tinggi rendahnya tingkat bunga pinjaman tergantung oleh tinggi rendahnya tingkat bunga simpanan, dimana semakin tinggi tingkat bunga simpanan maka semakin tinggi pula tingkat bunga pinjaman, begitupula sebaliknya. ${ }^{13}$ Asas penting yang selalu harus dijunjung tinggi oleh bank yang apabila tidak dilaksanakan maka bank kemungkinan akan dijauhi oleh publik, yakni asas kepercayaan (fiduciary), asas kerahasiaan (confidentiality), dan asas kehatihatian (prudentiality).

Menurut Pramono, sebagai lembaga kepercayaan masyarakat (fiduciary financial institution), bank mempunyai visi dan misi yang sangat mulia, yaitu sebagai sebuah lembaga yang diberi tugas untuk mengemban amanat pembangunan bangsa demi tercapainya peningkatan taraf hidup rakyat. ${ }^{14}$

\footnotetext{
${ }^{12}$ Sebaliknya, apabila suatu bank mengalami suatu kerugian dari selisih bunga, dimana tingkat bunga simpanan lebih besar dari tingkat kredit yang diberikan (lanable fund), maka terjadi negative spread.

${ }^{13}$ Martono, Op. Cit., hlm. 25.

${ }^{14}$ Nindyo Pramono, Hukum Perbankan 1, Program Pascasarjana Universitas Gadjah Mada Magister Hukum Bisnis, Yogyakarta, tanpa tahun, hlm. 1 .
} 
Menurut Djumhana, penghimpunan dana merupakan jasa utama yang ditawarkan dunia perbankan. Selanjutnya dana yang dihimpun dari masyarakat ini merupakan suatu tulang punggung atau basic dari dana yang dikelola oleh bank untuk memperoleh keuntungan. ${ }^{15}$

Menurut Santoso, ada beberapa manfaat dari jasa perbankan sebagai financial intermediary. Pertama, working balance, yakni untuk menunjang prosedur transaksi harian bisnis sehingga dapat memudahkan proses penerimaan dan pengeluaran pembayaran transaksi tersebut. Kedua, investment fund, yakni sebagai tempat investasi dari idle fund dengan harapan dapat memperoleh hasil bunga dari investasi tersebut. Ketiga, saving purpose, untuk tujuan keamanan penyimpanan uang, baik secara fisik maupun moril (inflasi, devaluasi, dan depresiasi). ${ }^{16}$

Sebagai bagian dari fungsi intermediasi perbankan, kredit menempati posisi yang sangat strategis dalam industri perbankan dimanapun. Dalam UU Perbankan,

\footnotetext{
${ }^{15}$ Muhammad Djumhana, Hukum Perbankan di Indonesia, PT. Citra Aditya Bakti, Bandung, 2000, hlm. 169.

${ }^{16}$ Ruddy Tri Santoso, Kredit Usaha Perbankan, Penerbit Andi, Yogyakarta, 1996, hlm. 5.
}

kredit adalah penyediaan uang atau tagihan yang dapat dipersamakan dengan itu, berdasarkan persetujuan atau kesepakatan pinjam-meminjam antara bank dengan pihak lain yang mewajibkan pihak peminjam untuk melunasi utangnya setelah jangka waktu tertentu dengan jumlah bunga, imbalan atau pembagian hasil keuntungan.

Dari pengertian tersebut, setidaknya terdapat empat unsur pokok kredit, yakni kepercayaan, waktu, risiko, dan prestasi. $^{17}$ Sementara Kasmir, menambah satu lagi unsur kredit dari unsur-unsur tersebut diatas sehingga menjadi lima unsur, yakni unsur kesepakatan. ${ }^{18}$ Oleh Ismail, unsur kesepakatan masuk dalam unsur perjanjian. Selanjutnya Ismail juga memasukkan kreditur dan debitur sebagai unsur-unsur dalam kredit. ${ }^{19}$

Penyaluran kredeit perbankan dalam prosesnya selalu memperhatikan Kualitas Aktiva Produktif (KAP), yakni penilaian aktiva produktif bank (kredit) dengan beberapa penggolongan kesehatan berdasarkan aspek-aspek tertentu dan terukur yang ditetapkan oleh suatu 125.

\footnotetext{
${ }^{17}$ H.R. Daeng Naja, Op. Cit., hlm. 124-
}

\footnotetext{
${ }^{18}$ Kasmir, Op. Cit., hlm. 95.

${ }^{19}$ Ismail, Op. Cit., hlm. 94-95.
} 
peraturan perbankan dan menghasilkan kolektibilitas, yakni keadaan pembayaran pokok atau angsuran dan bunga kredit oleh debitur serta tingkat kemungkinan diterimanya kembali dana tersebut. ${ }^{20}$ Dalam Keputusan Direksi Bank Indonesia Nomor 26/22/KEP/DIR tanggal 29 Mei 1993 dan Surat Edaran Bank Indonesia Nomor 26/4/BPPP tanggal 29 Mei 1993 Tentang Kualitas Aktiva Produktif dan Pembentukan Penyisihan Penghapusan Aktiva Produktif, menggolongkan kolektibilitas kredit dengan empat kriteria, yaitu lancar, kurang lancar, diragukan dan macet.

Namun, oleh Surat Keputusan Direksi Bank Indonesia Nomor 31/147/KEP/DIR tanggal 12 November 1998 sebagaimana telah diubah dengan Peraturan Bank Indonesia Nomor 4/6/PBI/2002 tanggal 6 September 2002 Tentang Perubahan Atas Surat Keputusan Direksi Bank Indonesia Nomor 31/147/KEP/DIR tanggal 12 November 1998 Tentang Kualitas Aktiva Produktif mengubah penggolongan kolektibilitas kredit menjadi lima kriteria, yakni lancar, dalam perhatian khusus, kurang 304. lancar, diragukan, dan macet, dengan menilai tiga faktor dalam menentukan kolektibilitas tersebut, yakni prospek usaha, kondisi keuangan, dan kemampuan membayar.

Pasal 2 UU Perbankan, menetapkan bahwa perbankan Indonesia dalam melakukan usahanya berasaskan demokrasi ekonomi berdasarkan Pancasila dan Undang-Undang Dasar Negara Republik Indonesia Tahun 1945 (UUD NRI 1945) dengan menggunakan prinsip kehati-hatian. Prinsip kehati-hatian adalah suatu prinsip yang menegaskan bahwa bank dalam menjalankan kegiatan usaha baik dalam menghimpun, terutama dalam penyaluran dana kepada masyarakat harus sangat berhati-hati agar bank selalu dalam keadaan sehat menjalankan usahanya dengan baik dan mematuhi ketentuan-ketentuan dan normanorma hukum yang berlaku di dunia perbankan. $^{21}$

Menurut Kasmir, sebelum kredit diberikan, bank terlebih dahulu mengadakan analisis kredit untuk meyakinkan bank itu sendiri

\footnotetext{
${ }^{21}$ Neni Sri Imaniyati, Pengantar Hukum Perbankan Indonesia, Refika Aditama, Bandung, 2010, hlm. 17.
} 
bahwa nasabah benar-benar dapat dipercaya dan kredit yang diberikan benar-benar aman, mencakupi latar belakang nasabah atau perusahaan, prospek usahanya, jaminan yang diberikan serta faktor-faktor lainnya. $^{22}$ Menurut Ismail, analisis kredit merupakan suatu proses analisis yang dilakukan oleh bank untuk menilai suatu permohonan kredit yang telah diajukan oleh calon debitur untuk mendapat keyakinan bahwa proyek yang akan dibiayai dengan kredit tersebut layak (feasible). ${ }^{23}$

Prinsip kehati-hatian itu dalam praktik perbankan diterjemahkan dalam ke dalam dua pengertian. Pertama, prinsip kehati-hatian terkait dengan masalah performance debitur, oleh karena itu sebelum kredit diberikan bank harus terlebih dahulu memeriksa dan menyelidiki kualitas calon debiturnya. Kedua, prinsip kehati-hatian terkait dengan masalah jaminan untuk membayar utang-utangnya, manakala debiturnya default atau colaps. ${ }^{24}$

\footnotetext{
${ }^{22}$ Kasmir, Op. Cit., hlm. 93.

${ }^{23}$ Ismail, Op. Cit., hlm. 111.

${ }^{24}$ Made Kamini, "Kegiatan Bank dalam Penghimunan Dana Masyarakat", Jurnal Legislasi Indonesia, Volume 3 Nomor 3 September 2006. Bandingkan dengan Mariam Darus Badrul Zaman, Perjanjian Kredit Bank, Alumni, Bandung, 1983, hlm. 72.
}

Secara teoritis, prinsip 5C merupakan pedoman yang baik bagi bank untuk menghindari terjadinya kredit macet karena mengandung tiga unsur pokok, yaitu faktor subjektif (moral), faktor objektif yang berkenaan dengan organisasi, administrasi modal dan keadaan ekonomi, serta faktor yuridis yang berkenaan dengan struktur yuridis dari badan usaha penerima kredit. ${ }^{25}$ Secara rinci, prinsip-prinsip yang dimaksud yakni;

a. Character (Watak)

Penilaian watak atau kepribadian calon debitur dimaksudkan untuk mengetahui kejujuran dan itikad baik calon debitur untuk melunasi dan mengembalikan pinjamannya, sehingga tidak akan menyulitkan bank di kemudian hari. ${ }^{26}$

b. Capacity (Kemampuan)

Penilaian kemampuan dapat diperoleh dengan meneliti tentang keahlian calon debitur dalam bidang usahanya dan kemampuan manajerialnya, sehingga bank yakin bahwa usaha yang akan dibiayainya dikelola oleh orangorang yang tepat, sehingga dalam

\footnotetext{
${ }^{25}$ Made Kamini, Ibid., hlm. 45.

${ }^{26}$ Djoni S. Gazali dan Rachmadi Usman, Op. Cit., hlm. 273.
} 
jangka waktu tertentu mampu melunasi atau mengembalikan pinjamannya. $^{27}$

c. Capital (Modal)

Penilaian modal dilakukan oleh bank dengan menganalisis terhadap posisi keuangan secara menyeluruh mengenai masa lalu dan yang akan datang, sehingga dapat diketahui kemampuan permodalan calon debitur dalam menunjang pembiayaan proyek atau usaha calon debitur yang bersangkutan. ${ }^{28}$

d. Collateral (Jaminan atau Agunan)

Pada dasarnya penilaian terhadap jaminan atau agunan dilakukan terhadap barang-barang yang akan dijaminkan oleh calon debitur pada bank, dilakukan dengan menaksir nilai barangnya apakah dapat menutup kredit yang akan diberikan bank seandainya debitur kelak tidak dapat melunasi utangnya dikemudian hari. ${ }^{29}$

Menurut Ismail, secara terperinci pertimbangan atas collateral antara lain dikenal dengan MAST, yakni marketability (mudah diperjualbelikan), ascertainability

\footnotetext{
${ }^{27}$ Ibid.

${ }^{28}$ Ibid., hlm. 274.

${ }^{29}$ Gatot Supramono, Op. Cit., hlm. 160.
}

(memilki stándard harga yang lebih pasti), stability of value (memiliki harga yang stabil), dan transferability (mudah dipindah baik secara fisik maupun yuridis). ${ }^{30}$

e. Condition (Kondisi)

Penilaian kondisi ekonomi dilakukan oleh bank dengan menganalisis keadaan pasar di dalam dan di luar negeri, baik masa lalu maupun yang akan datang, sehingga masa depan pemasaran dari hasil proyek atau usaha calon debitur yang dibiayai dapat pula diketahui. ${ }^{31}$

Selain itu, ada pula prinsip lain, seperti prinsip 5C, 3R, dan 6A. Prinsip 5P terdiri dari Party (golongan), Purpose (tujuan), Payment (pembayaran kembali), Profitability (kemampuan perusahaan dalam memperoleh keuntungan), dan Protection (perlindungan). Sementara Kasmir menambah dua prinsip lagi sehingga olehnya prinsip ini menjadi prinsip 7P, yakni personality (kepribadian) dan prospect (prospek usaha). Prinsip 3R terdiri dari return (hasil usaha yang dicapai), repayment

\footnotetext{
${ }^{30}$ Ismail, Op. Cit., hlm. 113-114.

${ }^{31}$ Djoni S. Gazali dan Rachmadi Usman, Op. Cit., hlm. 274.
} 
(kemampuan pembayaran kembali), dan risk Bearing Ability (kemampuan menanggung risiko). ${ }^{32}$

Prinsip 6A terdiri dari 6 aspek, meliputi aspek hukum, aspek pemasaran, aspek teknis, aspek manajemen, aspek keuangan, dan aspek sosial ekonomi. Sementara Kasmir, menambah satu lagi aspek yang harus dinilai, yakni aspek analisis mengenai dampak lingkungan (AMDAL), menyangkut analisis terhadap lingkungan baik darat, air atau udara jika proyek atau usaha tersebut dijalankan. Analisisis ini dilakukan secara mendalam apabila kredit tersebut disalurkan maka proyek yang dibiayai akan mengalami pencemaran lingkungan di sekitarnya, seperti tanah atau daratan menjadi gersang, air menjadi limbah berbau busuk atau berubah warna dan rasa, atau udara mengakibatkan polusi, berdebu, bising dan panas. ${ }^{33}$

Di samping prinsip-prinsip di atas, menurut Munir Fuady beberapa prinsip lain dalam hal pemberian kredit yang berhubungan dengan debitur yang harus diperhatikan oleh suatu bank, yaitu prinsip macthing, prinsip kesamaan

\footnotetext{
${ }^{32}$ Kasmir, Op. Cit., hlm. 106.

${ }^{33}$ Ibid., hlm. 109-110.
}

valuta, perbandingan antara pinjaman dan modal, dan prinsip perbandingan antara pinjaman dan aset (gearing ratio). ${ }^{34}$

$$
\text { Penjelasan umum UU }
$$

Perbankan menjelaskan bahwa prinsip kehati-hatian harus dipegang teguh, sedangkan ketentuan mengenai kegiatan usaha bank perlu disempurnakan terutama yang berkaitan dengan penyaluran dana termasuk di dalamnya peningkatan peranan analisis mengenai dampak lingkungan bagi perusahaan berskala besar dan berisiko tinggi. Lebih lanjut UU Perbankan menyebutkan bahwa dalam memberikan kredit, bank umum wajib mempunyai keyakinan atas kemampuan dan kesanggupan debitur untuk melunasi utangnya sesuai dengan yang diperjanjikan.

Dalam Pasal 8 UU Perbankan ditetapkan bahwa dalam memberikan kredit atau pembiayaan berasarkan prinsip syariah, bank umum wajib mempunyai keyakinan berdasarkan analisis yang mendalam atau itikad dan kemampuan serta kesanggupan nasabah debitur untuk melunasi utangnya atau mengembalikan pembiayaan dimaksud sesuai dengan

\footnotetext{
${ }^{34}$ Munir Fuady, Pengantar Hukum Bisnis, Bandung, PT. Citra Aditya Bakti, 2002, hlm. 113.
} 
yang diperjanjikan. Bank umum wajib memiliki dan menerapkan pedoman perkreditan dan pembiayaan berdasarkan prinsip syariah, sesuai dengan ketentuan yang ditetapkan oleh Bank Indonesia.

Pasal 11 ayat (1) UUU Perbankan menyebutkan bahwa Bank Indonesia menetapkan ketentuan mengenai batas maksimum pemberian kredit atau pembiayaan berdasarkan prinsip syariah, pemberian jaminan, penempatan investasi surat berharga atau hal lain yang serupa, yang dapat dilakukan oleh bank kepada peminjam atau sekelompok peminjam yang terkait, termasuk kepada perusahaan-perusahaan dalam kelompok yang sama dengan bank yang bersangkutan.

Berdasarkan landasan yuridis tersebut Bank Indonesia dari waktu ke waktu menetapkan ketentuan batas maksimum pemberian kredit yang secara konsep dapat berubahubah dari waktu ke waktu. Penetapan ini penting dilakukan agar bank melakukan penyebaran risiko dengan tidak terpusat pada peminjam, kelompok peminjam, atau bahkan kelompok tertentu dalam memberikan pinjaman, karena konsentrasi pemberian kredit dapat mengakibatkan risiko yang sangat besar bagi bank. ${ }^{35}$

Berdasarkan SK Direksi Bank Indonesia No 27/162/KEP/DIR dan SE Bank Indonesia No 27/7/UPPB masing-masing tanggal 31 Maret 1995 tentang Kewajiban Penyusunan dan Pelaksanaan Perkreditan Bank Bagi Bank Umum, maka perbankan sudah harus menentukan kebijaksaan pokok dalam perkreditan berupa Kebijaksanaan Perkreditan Bank (KPB) di mana ditentukan pokokpokok pengaturan mengenai tata cara penilaian setiap permohonan dan perpanjangan fasilitas kredit. Adapun ketentuan tersebut dikeluarkan agar bank-bank menyalurkan kreditnya secara sehat, karena penyusunan dan pelaksanaan Kebijaksanaan Perkreditan Bank (KPB) mempunyai cakupan luas mulai dari proses pengajuan kredit sampai dengan proses atau tata cara penyelesaian kredit.

Penyusunan dan pelaksanaan KPB sekurang-kurangnya mengatur mengenai prinsip kehati-hatian dalam perkreditan, organisasi, dan manajemen perkreditan, kebijaksanaan persetujuan kredit,

\footnotetext{
${ }^{35}$ HR.R. Daeng Naja, Op. Cit., hlm. 294
} 
dokumentasi dan administrasi kredit, pengawasan kredit, dan penyelesaian kredit bermasalah. Selain itu, harus pula ditetapkan secara jelas dan tegas adanya prinsip kehati-hatian dalam perkreditan yang sekurangkurangnya meliputi kebijakan pokok dalam perkreditan, tata cara penilaian kualitas kredit, dan profesionalisme, serta integritas pejabat perkreditan bank. Adapun kebijakan pokok dalam perkreditan, antara lain mengenai tata cara pemberian kredit yang sehat, pokokpokok pengaturan pemberian kredit kepada pihak terkait dengan bank, debitur-debitur besar tertentu, kredit yang mengandung risiko tinggi, serta kredit yang perlu dihindari. ${ }^{36}$

Menurut S. Sundari Arie, bank wajib memiliki komite kebijaksanaan kredit yang bertugas membantu direksi merumuskan dan mengawasi pelaksanaan perkreditan dan komite kredit yang bertugas membantu direksi mengevaluasi dan atau memutuskan permohonan kredit. ${ }^{37}$ Dengan demikian, penyusunan dan pelaksanaan KPB mengatur secara keseluruhan, mulai dari tahap inisiasi dan solisitasi calon debitur samapi dengan penyelesaian

\footnotetext{
${ }^{36}$ Ibid., hlm. 326.

${ }^{37}$ Ibid.
}

kredit, baik yang lancar maupun yang bermasalah.

Hal-hal pokok yang harus dimuat dan diatur dalam KPB masing-masing bank umum yang ditetapkan Pedoman Penyusunan Kebijaksanaan Perkreditan Bank (PPBKPB) yang terlampir dalam SK Direksi Bank Indonesia No 27/162/KEP/DIR tanggal 31 Maret 1995, mencakup sekurangkurangnya tentang prinsip kehatihatian dalam perkreditan, organisasi dan manajemen perkreditan, kebijaksanaan persetujuan kredit, dokumentasi dan administrasi kredit, pengawasan kredit, dan enyelesaian kredit bermasalah.

PPKPB menetapkan bahwa kredit yang dimaksud dalam KPB tidak terbatas hanya pada pemberian kredit yang lazim dibukukan dalam pos kredit pada aktiva dalam neraca bank, tetapi termasuk pula pemberian surat berharga yang disertai note purchase agreement atau perjanjian kredit, pemberian surat berharga lain yang diterbitkan oleh nasabah, pengambilalihan tagihan dalam rangka anjak piutang dan pemberian jaminan bank yang diantaranya meliputi akseptasi andosemen dan aval surat-surat berharga. 
Lalu, bagaimana dampak apabila pegawai bank dalam hal ini yang beurusan dengan kredit perbankan mengabaikan prinsip itu sendiri? Selama ini, banyak kasus kredit macet perbankan yang diakibatkan oleh salah dalam melakukan analisa.

Mantan seorang account officer Bank Rakyat Indonesia (BRI), Sofyan Sidi Umar, dituntut hukuman 18 bulan penjara dan denda $\mathrm{Rp} 50$ juta subsidair 4 bulan kurungan, karena dianggap terbukti bersalah dalam kasus kredit macet. Sofyan dinilai tidak cermat melakukan analisis permohonan kredit modal kerja yang diajukan CV. Asia Jaya. Sofyan dianggap menyalahgunakan kewenangannya sebagaimana diancam pidana Pasal 3 UndangUndang Nomor 31 Tahun 1999 tentang Pemberantasan Tindak Pidana Korupsi Sebagaimana Telah Diubah Dengan Undang-Undang Nomor 20 Tahun 2001. ${ }^{38}$

\footnotetext{
${ }^{38}$ Selain Sofyan, dalam persidangan terpisah mantan pimpinan kantor cabang khusus BRI DKI Jakarta, Opi Sofyan Suryadi juga dituntut jaksa dengan hukuman 2 tahun penjara dan denda Rp 50 juta subsidair 4 bulan kurungan. Opi dinilai terbukti menyalahgunakan kewenangan terkait pemberian kredit modal kerja kepada CV Asia Jaya, CV Bumi Sentosa dan CV Trijaya yang mengakibatkan kerugian keuangan negara Rp 45 miliar. Lihat di http://news.detik.com/read/2013/07/09/172320/22 97174/10/kasus-kredit-macet-eks-karyawan-bri-
}

Selain kasus yang melibatkan karyawan Bank BRI tersebut di atas, masih banyak kasus serupa yang pada pokoknya merupakan pengabaian atau ketidakcermatan dalam menganalisa kredit yang diajukan, sehingga mengakibatkan terjadinya kredit macet. Contoh lain adalah kasus kredit macet Rp 35, 2 Miliar di Bank Riau Kepri dengan terdakwa Arya Wijaya, Direktur PT. Saras Perkasa. $^{39}$ Arya Wijaya diajukan ke persidangan karena didakwa telah melakukan serangkaian perbuatan tindak pidana korupsi kredit macet senilai Rp 35,2 miliar di Bank Riau Kepri Batam, yang menjerat sejumlah petinggi Bank Riau Kepri di Pekanbaru. Terdakwa Arya Wijaya pada 28 Juni 2003 mendirikan PT. Saras Perkara di Batam. Hanya berselang dua hari, tepatnya tanggal 30 Juni 2003, ia mengajukan kredit ke Bank Riau Kepri senilai $\operatorname{Rp} 35,2$ miliar. Padahal, ketika permohonan kredit diajukan ke Bank Riau Kepri, PT. Saras Perkasa belum terdaftar di Kementrian Hukum dan Hak Asai

dituntut-18-bulan-penjara?nd771104bcj, diakses pada tanggal 14 November 2017, 15. 40 WIB.

${ }^{39}$ Pada sidang sebelumnya, majelis hakim Pengadilan Tipikor Pekanbaru telah memvonis sejumlah petinggi Bank Riau, salah satunya adalah Zulkifli Thalib, Direktur Bank Riau Kepri kantor Pusat Pekanbaru. 
Manusia (HAM) Jakarta, tetapi nekat mengajukan kredit yang nilainya puluhan miliar rupiah. Untuk melengkapi permohonan kredit tersebut, Arya Wijaya melampirkan jaminan atau agunan sebanyak 27 pintu ruko dan sebuah bangunan mall yang diperolehnya melalui take over dari PT Wahana. PT. Wahana merupakan nasabah Bank Riau Kepri. Saat ruko dan mall diagunkan terdakwa ke Bank Riau Kepri, kondisinya masih terbengkalai alias belum rampung dikerjakan. ${ }^{40}$

Sementara itu, nasabah atas nama Rosinta Simarmata dan David Silalahi terbukti bersalah di Pengadilan Negeri Bangkinang karena mengklaim lahan sawit milik orang lain. Pengadilan memutuskan keduanya divonis delapan bulan kurungan. Kebun sawit milik orang lain inilah yang juga dijadikan agunan di Bank Negara Indonesia (Bank BNI) Cabang Pekanbaru. Rosinta Simarmata dan David Silalahidengan menggunakan surat sertifikat tanah yang palsu, mengajukan kredit senilai $\mathrm{Rp}$ 4,9 miliar di Bank BNI.

\footnotetext{
${ }^{40}$ Lihat di http://www.inhilklik.com/2013/ 10/kasus-kredit-macet-rp-35-2-miliar-di.html, diakses pada tanggal 14 November 2017, diakses pada pukul 15.50 WIB.
}

Anehnya, pihak bank menyetujui permohonan kredit tersebut. Bank BNI tidak objektif dalam memberikan pinjaman kepada Rosinta Simarmata dan David Silalahi. Sebab, lahan yang diagunkan ke bank tersebut bukanlah miliknya, sehingga akhirnya terjadi kredit macet. Kasus kredit macet ini terungkap saat puluhan orang dari Lembaga Swadaya Masyarakat (LSM) Riau Bersih berunjuk rasa di kantor Kejaksaan Tinggi (Kejati) Riau di Pekanbaru. Saat itu massa pengunjuk rasa mendesak pihak Kejati Riau mengusut kasus mafia perbankan yang terjadi di Bank BNI Cabang 46 Pekanbaru. Pimpinan bank ini dituding pengunjuk rasa telah menyalahgunakan wewenang pemberian kredit kepada seorang nasabah yang bernama Rosita Simarmata. ${ }^{41}$ Padahal angunan yang dijaminkan Rosita Simarmata dalam bentuk lahan perkebunan sawit, merupakan lahan milik orang lain. Kuat dugaan, dalam pemberian kredit ini, pihak BNI 46 telah kongkalingkong dengan Rosita

\footnotetext{
${ }^{41}$ Lihat di http://www.pewarta-indonesia. com/berita/hukum/11062-kredit-macet-capairp49-m-di-bni-capem-pekanbaru.html, diakses pada tanggal 14 November 2017, diakses pada pukul 16.00 WIB.
} 
Simarmata. Karena, anggunan Rosita

Simarmata ini ternyata palsu.

Dari beberapa contoh yang diuraikan tersebut di atas, sudah terang bahwa implikasi pengabaian prinsip kehati-hatian perbankan (prudential banking) dalam proses penyaluran kredit perbankan di Indonesia yang tertuang dalam prinsip 5C dan beberapa prinsip lain yang dikenal, sangat berbahaya terhadap kelangsungan insustri perbankan. Analisis terhadap agunan, serta kecermatan dalam menganalisis aspek lain pun patut menjadi pertimbangan utama seorang pegawai bank dalam menganalisis kredit yang diajukan

\section{PENUTUP}

Analisi kredit adalah suatu langkah atau tahapan pemberian kredit yang harus diatur dalam pedoman perkreditan masing-masing bank, yang mana pembuatan dan penyusunannya dalam rangka pemberian kredit perbankan merupakan salah satu bagian dalam melaksanakan prinsip kehati-hatian dalam kegiatan perbankan. Analisis kredit mempunyai peranan yang penting dalam pemberian kredit dan berfungsi antara lain untuk mengetahui kelayakan permohonan kredit dan usahanya, kemampuan dan kesanggupan yang bersangkutan untuk melunasi kreditnya, serta risiko yang terkait dan yang mungkin timbul sehubungan dengan pemberian kredit tersebut. Merujuk pada beberapa kasus yang melibatkan beberapa bank tersebut diatas, yang hampir semuanya diakibatkan oleh salah dalam melakukan analisis sbagai manifestasi dari prinsip kehati-hatian perbankan, sudah seharusnya perbankan lebih berhati-hati lagi dalam menganalisis kredit yang diajukan sebagaimana yang dimanatkan oleh UU Perbankan. Hasil analisis yang baik tentu pula berimplikasi baik terhadap kinerja perbankan itu sendiri.

\section{E. DAFTAR PUSTAKA}

Diantha, I Made Pasek. 2017. Metodologi Penelitian Hukum Normatif dalam Justifikasi Teori Hukum. Kencana Prenada Media Group, Jakarta.

Djumhana, Muhammad. 2000. Hukum Perbankan di Indonesia. PT. Citra Adtya Bakti, Bandung.

Gazali, Djoni S. dan Rachmadi Usman. 2012. Hukum Perbankan. Sinar Grafika, Jakarta.

Imaniyati, Neni Sri Imaniyati. 2010. Pengantar Hukum Perbankan 
Indonesia. Refika Aditama, Bandung.

Ismail. 2011. Manajemen Perbankan dari Teori Menuju Aplikasi. Kencana Prenada Media Group, Jakarta.

Kasmir. 2002. Bank dan Lembaga Keuangan Lainnya (Edisi Keenam). PT. Raja Grafindo Persada, Jakarta.

Lihat di http://news.detik.com/read/ 2013/07/09/172320/2297174/10/k asus-kredit-macet-eks-karyawanbri-dituntut-18-bulan-penjara? nd771104bcj diakses pada tanggal 14 November 2017., 15. 40 WIB.

Lihat di http://www.inhilklik.com/2013/ 10/kasus-kredit-macet-rp-35-2miliar-di.html diakses pada tanggal 14 November 2017, diakses pada pukul 15.50 WIB.

Lihat di http://www.pewartaindonesia.com/berita/hukum/1106 2-kredit-macet-capai-rp49-m-dibni-capem-pekanbaru.html, diakses pada tanggal 13 Januari 2014, diakses pada pukul 16.00 WIB.

Made Kamini. "Kegiatan Bank Dalam Penghimunan Dana Masyarakat". Jurnal Legislasi Indonesia. Volume 3 Nomor 3 September 2006. Direktorat Jendral Peraturan Perundang-Undangan Departemen Hukum dan Ham RI, Jakarta.

Martono. 2004. Bank dan Lembaga Keuangan Lainnya. Ekonisia Fakultas Ekonomi Universitas Islam Indonesia, Yogyakarta.

Marzuki, Peter Mahmud. 2016. Penelitian Hukum (Edisi Revisi).
Kencana Prenada Media Group, Jakarta.

Naja, HR.R. Daeng. 2005. Hukum Kredit dan Bank Garansi. Citra Aditya Bakti, Bandung.

Pramono, Nindyo. Tanpa Tahun. Hukum Perbankan 1. Program Pascasarjana Universitas Gadjah Mada Magister Hukum Bisnis. Yogyakarta.

Santoso, Ruddy Tri. 1996. Kredit Usaha Perbankan. Penerbit Andi, Yogyakarta.

Supramono, Gatot. 2009. Perbankan dan Masalah Kredit Suatu Tinjauan di Bidang Yuridis. Rineka Cipta, Jakarta.

Mariam Darus Badrul Zaman. 1983. Perjanjian Kredit Bank. Alumni, Bandung.

Republik Indonesia. Undang-Undang Nomor 10 Tahun 1998 Tentang Perubahan Atas Undang-Undang Nomor 7 Tahun 1992 Tentang Perbankan. 